\title{
BUSINESS MODEL INNOUATION FOR IOT SOLUTIONS: AN EXPLORATORY STUDY OF STRATEGIC FAGTORS AND EXPECTED OUTCOMES
}

\author{
Florin Sabin Foltean ${ }^{1 *}$ and Bogdana Glovațchi ${ }^{2}$ \\ ${ }^{1) 2)}$ West University of Timisoara, Romania
}

\author{
Please cite this article as: \\ Foltean, F.S. and Glovațchi, B., 2021. Business Model \\ Innovation for IoT Solutions: An Exploratory Study of \\ Strategic Factors and Expected Outcomes. Amfiteatru \\ Economic, 23(57), pp.392-411.
}

\section{Article History}

Received: 27 December 2020

Revised: 30 January 2021

Accepted: 10 March 2021

\section{DOI: $10.24818 / \mathrm{EA} / 2021 / 57 / 392$}

\begin{abstract}
Business model innovation is a key success factor for IT companies competing in technologically uncertain environments. Despite the need of IoT solution developers to renew their business models to effectively create value for customers and capture value for the company, the strategic factors of business model innovation for IoT solutions have remained under-researched so far. The paper addresses this knowledge gap by exploring the strategic factors of business model innovation and its results from the perspective of RBV (Resource-Based View) theory. The theoretical foundation of this research is based on the literature of the business model innovation and the strategic marketing literature. In the empirical exploration of the strategic factors of the business model innovation, we adopted a qualitative research strategy having as methodological basis Grounded theory. More precisely, we conducted 12 semi-structured interviews with top managers at IT companies operating in Romania that have successfully developed IoT solutions. Proactive market orientation, technology orientation, entrepreneurial orientation, and adaptive marketing capabilities have been identified as strategic factors of business model innovation for IoT solutions, while competitive advantage and customer satisfaction as the main expected outcomes.
\end{abstract}

Keywords: Proactive market orientation; technology orientation; entrepreneurial orientation; adaptive marketing capabilities; business model innovation; Internet of Things (IoT)

JEL Classification: M15, M31, O33

* Corresponding author, Florin Sabin Foltean - e-mail: florin.foltean@e-uvt.ro

Authors' ORCID:

Florin Sabin Foltean: orcid.org/0000-0002-0480-8221

Bogdana Glovațchi: orcid.org/0000-0002-0923-0799 


\section{Introduction}

IoT technologies have a disruptive potential in many industries and markets. The proliferation of smart products and services, the blurring of industry boundaries, increasing the number of consumers with experience in using products that incorporate new technologies and adopt new behaviours, the implementation of new business models and competitive practices and the emergence of new business regulations are just some of the current trends in the business environment. Incumbents are threatened by the rapid pace of digital transformation, the entry of new competitors with unconventional business models, and by the changing needs and behaviours of digitally savvy customers (Verhoef et al., 2019). To cope with the disruption challenges, incumbents need to adopt next generation technologies that allow the development of new value propositions and business models and the development of new organizational capabilities to survive and thrive in an uncertain and fast changing environment. Despite the fact that strategists and entrepreneurs need guidance in business model innovation for digital-enhanced products and services, this phenomenon remains under-explored (Foss and Saebi, 2018). Moreover, the role of the company's strategic orientations and adaptive marketing capabilities in business model innovation for IoT solutions remains insufficiently understood. Consequently, this research contributes to filling this knowledge gap by exploring the strategic factors of business model innovation for IoT solutions and the outcomes expected by managers. We studied this phenomenon from the perspective of RBV (Resource-Based View) theory, aiming to identify the company's strategic orientations and marketing capabilities that lead to business model innovation for IoT solutions, as well as the outcomes expected by managers. We used previous research on business model innovation (Clauss, 2017; Foss and Saebi 2018), strategic orientations (Miller, 1983; Gatignon and Xuereb, 1987; Narver, Slater and MacLachlan, 2004) and marketing capabilities (Day, 2011; Guo et al., 2018) to inform our theoretical approach. Given the emerging nature of the business model innovation phenomenon for IoT solutions, we adopted the Grounded theory perspective as the methodological foundation of our exploratory empirical study. The qualitative research conducted on a sample of 12 top managers at high-tech companies that develop and deliver IoT solutions provides empirical support for strategic factors and expected outcomes of business model innovation for IoT solutions.

The paper brings certain contributions to the literature on business model innovation and strategic marketing that are relevant from both a theoretical and managerial perspective. First, the paper expands the scope of RBV theory in researching business model innovation in the context of next-generation digital technologies, such as IoT. Second, we found that proactive market orientation, technology orientation, entrepreneurial orientation, and adaptive marketing capabilities are important strategic factors of business model innovation for IoT solutions. Third, the competitive advantage and customer satisfaction were revealed as the main outcomes expected by managers following business model innovation for IoT solutions.

The remainder of this paper is structured as follows. First, we review the literature related to the business model innovation, strategic orientations, and marketing capabilities. The next section presents the methodology of qualitative research, the sample, the topics of semi-structured interviews and the coding process. Then, we will present the findings from the analysis of qualitative data. Finally, in the conclusion section, we will draw theoretical contributions, managerial implications, limitations and directions for further research. 


\section{Review of the scientific literature}

IoT represents "a system of uniquely identifiable and connected constituents (termed as Internet-connected constituents) capable of virtual representation and virtual accessibility leading to an Internet-like structure for remote locating, sensing, and/or operating the constituents with real-time data/information flows between them, thus resulting in the system as a whole being able to be augmented to achieve a greater variety of outcomes in a dynamic and agile manner" (Ng and Wakenshaw, 2017, p. 6). IoT-related technologies (e.g., RFID tags, sensors, actuators, microchips, software, cloud computing, wireless communications, and the Internet) are changing the nature of products, making them smarter and better connected (Porter and Heppelmann, 2014). Smart and connected products generate real-time usage data and allow the company to continuously connect with the customer through the product (Siggelkow and Terwiesch, 2019). These transformations are taking place in a growing number of traditional industries for consumer and industrial products and services, such as smart watches, cars, light bulbs, thermostats, industrial equipment, heavy machinery, energy equipment and wearable items.

The new capabilities of smart products, the new services they can offer, and their greater reliability have the potential to increase the value delivered to customers and the value captured by companies. From the company's perspective, IoT-enhanced products and services disrupt value chains, industry boundaries and structures, create new markets and unlock competitive value (Porter and Heppelmann, 2014). From a customer perspective, IoT significantly changes the customer experience (Hoffman and Novak, 2018) and customer relationships with smart and connected products (Verhoef et al., 2017; Novak and Hoffman, 2019). To meet these challenges, companies need to renew their strategic vision, positioning and partnerships (Porter and Heppelmann, 2014), develop new business models (Djkman et al., 2015), reconfigure operational processes and build new capabilities (Brous, Janssen and Herder, 2020). The market success of new enhanced IoT products and services developed by companies is more likely if managers, along with technological innovation, also facilitate the development of organizational resources that drive business model innovation in line with customer expectations.

The development of new digital technologies and digital businesses over the past three decades led to a more strategic understanding of the business model concept as a tool in managerial decision making (Wirtz et al., 2016) and as a unit of analysis in strategic management of the processes of value creation and capture by the company (Zott, Amit and Massa, 2011). The business model, as a distinct concept from strategy (Casadesus-Masanell and Ricart, 2010), was conceptualized as "an architecture for how a firm creates and delivers value to customers and the mechanisms employed to capture a share of that value" (Teece, 2018, p.40). Osterwalder, Pigneur and Tucci (2005) identified nine building blocks which they centred on four main pillars: product (value proposition); customer interface (target customers; distribution channel; customer relationships); infrastructure management (value configuration; core competency; partner network); and financial aspects (cost structure; revenue model). The defining feature of the business model is represented by the complementarities of the activities underlying the creation, delivery and capture of value (Foss and Saebi, 2018). The level of differentiation, effectiveness and efficiency of these components of the business model has a significant impact on creating the company's competitive advantage (Teece, 2010). Moreover, managerial decisions regarding the design of new business models have become critical in the context in which next-generation digital 
technologies have a disruptive potential in different industries (Porter and Heppelmann, 2014). More precisely, IoT technologies have a significant contribution in the innovation of the business model of manufacturing companies in the direction of servitization (Paiola and Gebauer, 2020). Consequently, the concept of business model innovation has become increasingly relevant for both managers and researchers (Taran, Boer and Lindgren, 2015).

Technological changes and the intensification of competition over the last two decades require a dynamic perspective on the business model. New technologies with disruptive potential allow the development of innovative ways to meet customer needs more effectively and require new business models appropriate for creating and capturing value (Teece, 2010). Previous literature (Mezger, 2014; Taran, Boer and Lindgren, 2015; Wirtz, 2016) provides three main conceptualizations of business model innovation. First, business model innovation is widely understood as "the design process for giving birth to a fairly new business model on the market, which is accompanied by an adjustment of the value proposition and/or the value constellation and aims at generating or securing a sustainable competitive advantage" (Wirtz, 2016, p. 189). Clauss (2017) developed a three-dimensional conceptualization of this construct: a) value creation innovation (new competencies, new technology/equipment, new partnerships, and new processes); b) value proposition innovation (new offerings, new customers and markets, new channels, and new customer relationships); and c) value capture innovation (new revenue models and new cost structures). Second, Mezger (2014) proposed a definition of business model innovation as a dynamic capability that consists of three dimensions: a) the ability to sense opportunities for new business models; b) the ability to seize these opportunities by developing new business models; and c) the ability to reconfigure the company's capabilities and assets to enable the implementation of a new business model. Third, Taran, Boer and Lindgren (2015) argued that business model innovation can be understood not only as a process, but also as a result of this process. Some research has empirically investigated the role of strategic orientations and organizational capabilities in business model innovation. For example, Ciampi et al. (2021) empirically validated the positive influence of entrepreneurial orientation on business model innovation, and Mütterlein and Kunz (2017) found that entrepreneurial orientation has a positive influence on the innovation of two components of the business model, respectively on the development of an innovative value proposition and on the innovation of the value creation process. Guo et al. (2020) identified a beneficial impact of the technology and customer orientations adopted in the business model design process on the performance of start-up companies. Tarkiainen, Ritala, and Sainio (2015) found the antecedent role of market sensing capability in the business model innovation process. However, the role of market orientation and marketing capabilities in the business model innovation process in IT\&C companies has not been the subject of empirical studies to date.

The field of strategic management is dominated is dominated by theoretical studies that provide the conceptual basis for describing the business model innovation process in the practice of organizations. However, advancing the understanding of the business model innovation phenomenon requires empirical studies to identify and test its relationships with antecedents and performance outcomes (Foss and Saebi, 2018). Consequently, we investigated the phenomenon of business model innovation from the perspective of RBV theory according to which differences in company performance are explained by the availability and development of valuable, rare, inimitable and non-substitutable resources by the company (Barney, 1991). Moreover, Barney (2014) argued that a "constellation of 
resources and capabilities" (p. 25) has an essential contribution to the strategy that ensures the competitiveness and performance of the organization. RBV theory has been the theoretical foundation of many previous researches in strategic management and marketing (Kozlenkova, Samaha and Palmatier, 2014).

Market orientation positively influences the level of innovation which, in turn, leads to superior firm performance (Han, Kim and Srivastava, 1998). From the perspective of innovation type, Zhou, Yim and Tse (2005) found that market orientation positively influences technology-based innovations, and Najafi-Tavani, Sharifi and Najafi-Tavani (2016) identified a positive influence of market orientation on the performance of a new product. From the perspective of market uncertainty, Gatignon and Xuereb (1997) found that customer orientation positively influences the market performance of innovation in environments with high uncertainty. However, some critics have questioned the value of market orientation in the context of innovation (Berthon, Hulbert and Pitt, 1999). Consequently, Narver, Slater and MacLachlan (2004) argued that the market orientation of the company lies in two types of behaviour: responsive market orientation that meets the needs expressed by the customer, and proactive market orientation that uncover latent needs and anticipates future ones and take the initiative in developing new solutions. Empirical findings have shown that proactive market orientation is positively related to the market success of a new product (Narver, Slater and MacLachlan, 2004; Lamore, Berkowitz and Farrington, 2013), supporting the company's long-term profitability and position on the market (Jaeger, Zacharias and Brettel, 2016). More specifically, Blocker et al. (2011) found that proactive customer orientation is the most important factor in creating customer value that leads to a higher level of customer satisfaction and loyalty. The value of proactive market orientation has proven to be higher in times of greater technological uncertainty, creating opportunities for more radical innovation (Tsai, Chou and Kuo, 2008). However, in markets with a culture of avoiding uncertainty, increasing the level of proactive market orientation, beyond a certain threshold, can negatively affect market performance due to customer resistance in learning new behaviours (Ozdemir, Kandemir and Eng, 2017). Recently, three proactive market strategies have been proposed as useful in the process of creating value for customers and creating new markets: market shaping, customer involvement and innovative leadership (Brege and Kindstrom, 2020). Consequently, we will focus on exploring the role of proactive market orientation in business model innovation in the context of the technological uncertainty generated by disruptive digital technologies.

Company's survival in technologically uncertain environments requires a high level of innovation in adopting new technologies and developing new solutions to meet the needs of new customers (Gatignon and Xuereb, 1997). Innovative and proactive companies have adopted a strategic technology orientation defined as "the ability and will to acquire a substantial technological background and use it in the development of new products" (Gatignon and Xuereb, 1997, p. 78). These companies are focused on monitoring future technological developments to identify and evaluate the business potential of new technologies and their impact on the evolution of the company and its market. Previous literature provides empirical evidence to support the contribution of customer orientation and technology orientation to the success of innovation in specific contexts, such as high-tech industries (Zhou, Yim and Tse, 2005) and markets with high uncertainty (Gatignon and Xuereb, 1997). Hortinha, Lages and Lages (2011) found that customer orientation and technology orientation play equally important roles in enhancing exploratory innovation capabilities. Moreover, Zhou and Li (2010) identified stronger effects on adaptive capability 
of technology orientation compared to customer orientation in markets with a high level of demand uncertainty. More recently, Adams, Bodas Freitas and Fontana (2019) have discovered a higher level of performance of companies with a combined customer and technology orientation compared to those oriented only to the customer or only to technology. Technology orientation is the most important strategic orientation when companies want to ensure the competitive superiority of their innovations (Gatignon and Xuereb, 1997).

Entrepreneurial orientation has been conceptualized in terms of decision-making norms (Morris and Paul, 1987), management style (Covin and Slevin, 1998), managerial capacity (Avlonitis and Salavou, 2007), and processes and practices (Lumpkin and Dess, 1996) and is generally characterized by innovation, proactivity and calculated risk-taking. In other words, entrepreneurial firms develop radical innovations, adopt proactive strategies, and take calculated risks in new product projects whose results are uncertain (Zahra and Neubaum, 1998) and to search for new market opportunities (Hult and Ketchen, 2001). For example, in the service sector, Karimi and Walter (2016) discovered that proactivity and risk-taking directly influence the disruptive innovation of the business model. Entrepreneurial organizations are more likely to learn through exploration and experimentation, challenging current thinking and creating generative learning (Slater and Narver, 1995). Previous empirical research supports the notion that entrepreneurial orientation enhances organizational capabilities. For example, Zhao et al. (2011) found that entrepreneurial orientation positively influences the capability of experiential learning, while Chen, Li and Evans (2012) provide empirical support for the idea that entrepreneurial orientation enhances a company's exploitation and exploration capabilities. Furthermore, Zhou, Yim and Li (2005) found a positive influence of entrepreneurial orientation on technology and market-based innovations. Regarding the relationship between entrepreneurial orientation and performance, Saeed, Yousafzai and Engelen (2014) found a higher impact of this orientation in developing countries than in developed ones, without any differences in the intensity of this relationship determined by market size. More recently, Martin and Javalgi (2016) validated the positive influence of entrepreneurial orientation on performance in an international context, both in highly competitive environments and in those with a low level of competitive intensity.

In the strategic management literature, adaptability has been defined as "the firm's ability to identify and capitalize on emerging market opportunities" (Wang and Ahmed, 2007, p. 37). In the case of small firms, the results of empirical research have shown that adaptability leads to high financial performance and performance in the case of new products (Chryssochoidis, Dousios and Tzokas, 2016). In the field of strategic marketing, previous research has conceptualized adaptability as a multidimensional construct which consists of the ability to scan the market, the ability to adapt the product-market and the ability to respond quickly to market changes (Oktemgil and Greenley, 1997). Adaptive marketing capabilities allow an early detection of new market trends and a faster response to them (Day, 2011; Jayachandran, Hewett and Kaufman, 2004). Day (2011) proposed three adaptive marketing capabilities that lead to a sustainable competitive advantage in dynamic and uncertain environments: a) vigilant market learning capability; b) market experimentation capability; and c) open marketing capability. Previous marketing research provides empirical evidence to support the notion that dynamic marketing capabilities have a positive impact on firm performance (Fang and Zou, 2009; Guo et al., 2018). Adaptive marketing capabilities become essential in enabling a better market performance in uncertain environments (Guo et al., 2018) where next-generation digital technologies with disruptive potential proliferate. 


\section{Research methodology}

This research focused on exploring strategic factors and expected outcomes of business model innovation in organizations that have successfully developed IoT solutions. Therefore, we looked for answers to three research questions: a) what strategic orientations of the company lead to the innovation of the business model? b) What marketing capabilities are involved in this process? c) What are the expected outcomes of business model innovation for IoT solutions?

Due to the shortage of previous theoretical and empirical studies aimed at explaining strategic factors of business model innovation in general, in the context of IoT solutions in particular, we have chosen an exploratory research approach. More specifically, we decided to adopt the model of Grounded theory in our qualitative research design. This decision is justified by the fact that the grounding of a theory in qualitative data is recommended for research topics not consistently informed by any previous theories (Amit and Zott, 2001). To this end, we collected qualitative data through semi-structured interviews with 12 top managers at companies with operations in Romania that, through pioneering, have successfully developed and launched new IoT solutions for operations management, logistics, retailing, public utilities and services, and environmental sustainability (Table no. 1).

Table no. 1: Sample profile

\begin{tabular}{|l|l|l|}
\hline Participants & \multicolumn{1}{|c|}{ Role } & \multicolumn{1}{c|}{ The company's IoT solution projects } \\
\hline Participant 1 & General manager & Operations management \\
\hline Participant 2 & General manager & Public utilities and services \\
\hline Participant 3 & General manager & Environmental sustainability \\
\hline Participant 4 & General manager & Logistics \\
\hline Participant 5 & General manager & Operations management \\
\hline Participant 6 & General manager & Retailing \\
\hline Participant 7 & R\& D director & Operations management \\
\hline Participant 8 & R\& D director & Public utilities and services \\
\hline Participant 9 & R\& D director & Operations management \\
\hline Participant 10 & R\& D director & Logistics \\
\hline Participant 11 & Sales manager & Operations management \\
\hline Participant 12 & Sales manager & Public utilities and services \\
\hline
\end{tabular}

The sample was constructed using the convenience sampling method. Participants were included in the sample based on their knowledge and experience in managing projects for the successful development and launch of IoT solutions by their companies. These managers were qualified to share their companies experience in IoT projects, which is useful in revealing a realistic perspective on the phenomenon studied. In addition, their views and critical assessments have helped us develop a deeper understanding of business model innovation for IoT solutions. The sample size of 12 managers is comparable to that of samples used in other qualitative research based on semi-structured interviews that explored aspects of business model innovation in the context of adopting next-generation digital technologies (Alberti-Alhtaybat, Al-Htaybat and Hutaibat, 2019; Barbour and Luiz, 2019). Moreover, Guest, Bunce and Johnson (2006) found through an experiment that the number of 12 interviews represents a threshold for data saturation in the case of in-depth interviews. Also, this sample size is justified in the case of exploring an emerging 
phenomenon such as the development of IoT solutions in which companies in the IT\&C sector around the world and in Romania have started to get involved relatively recently.

The semi-structured interviews were conducted by the first author, being assisted and technically supported by the second author, and took place between February and December 2019. The interviews were recorded with the permission of the participants and the both authors took notes during the interviews. In order to stimulate the free expression of their own ideas and opinions, participants were reassured that their personal data and their company's data would be treated confidentially and anonymously. The interviews were conducted based on an interview guide containing two broad topics related to managers' perceptions of the potential of IoT technologies and the process of developing and launching new IoT solutions. The interview began with an introduction by the interviewer who explained the purpose of the research and a broad question that addresses the participants' perspective on the phenomenon of IoT adoption by organizations. The interviewer gave all participants the freedom to structure their ideas on their own. To ensure the generation of useful information to answer the research questions of this study, the interviewer asked further questions to go in depth into some of the ideas presented by the participants. The interviewer did not suggest any ideas or formulate any opinions to avoid influencing the participants' line of reasoning.

The qualitative data obtained were manually coded, analyzed and interpreted. Following the recommendation of Saldaña (2013), throughout the entire process of conducting interviews, reading field notes and transcripts, as well as coding, we noted the reflections and ideas we generated in the form of analytical memos. We analyzed these qualitative data following the coding model presented by Saldaña (2013), in a first round of coding using codes invoked directly from the interviewees' vocabulary. In doing so, a first round of coding was conducted using invoked and process codes for interview transcripts. A second cycle followed using theoretical coding method to arrive at categories that were considered to be first-order constructs, and themes as second - and third-order constructs.

In the first coding cycle we used invoked codes and process codes to summarize the topics of the interview excerpts. Invoked codes were extracted from the terminology used by the interview participants. As examples of such codes we mention the following: technology; business model; proactive; first mover; vision; advantage; satisfaction; (corporate) image; customer needs; market; alliance. At the same time, we used process codes to capture the actions taken in business model innovation. Examples of such process codes are: decision; innovation; experiment; understand; project management, market development. In the second coding cycle we used theoretical coding to identify the categories and themes that lead us to the first-, second - and third-order constructs. In doing so, we relied on the literature of business model innovation and strategic marketing to identify the theoretical constructs relevant to the phenomenon we investigated.

The aggregation of codes into categories (first-order constructs) and themes (second - and third-order constructs) was achieved by the theoretical coding method recommended in Grounded theory, which allowed, in addition to focused coding and axial coding, integration and synthesis of categories in order to develop a theory (Saldaña, 2013). This coding method has been used previously in qualitative research (Kohtamäki et al., 2020). We used as reference points in the analytical reflection the measurement scales of the following constructs that were previously developed and validated in the literature: a) innovation of the business model, respectively innovation of the value creation process, 
innovation of the value proposition and innovation of the value capture process (Clauss, 2017); b) proactive market orientation (Narver and Slater, 2004); c) technology orientation (Gatignon and Xuereb, 1987); d) entrepreneurial orientation (Miller, 1983); e) adaptive marketing capabilities, namely vigilant market learning, market experimentation and open marketing (Day, 2011; Guo et al., 2018); f) facilitative leadership (Slater and Narver, 1995); and g) organizational culture (Moorman, 1995). The way of aggregating the constructs is presented in the table in the next section. To increase confidence in the results of the coding process, two general managers and two business consultants separately assessed the congruence of codes, categories and themes.

\section{Results}

In the following sections we will present the main constructs that emerged from the coding process as supported by interview excerpts.

\subsection{Business model innovation for IoT solutions}

To identify the elements of the business model for IoT solutions on which innovation efforts revolve, we adopted Clauss's (2017) conceptualization of business model innovation as a third-order construct consisting of three second-order constructs: a) value creation innovation, with four dimensions (i.e. new competencies, new technology and/or equipment, new partnerships and new processes); b) value proposition innovation, with four dimensions (new offers, new customers and markets, new channels and new customer relationships); and c) value capture innovation with two dimensions (new revenue models and new cost structures) (Table no. 2).

A. Value creation innovation. The company's commitment to developing IoT solutions triggers a learning process in order to develop complementary skills for innovation, i.e. technical, business and marketing skills. Managers try to capitalize on the company core competencies for developing IoT solutions, so that employees can more easily develop new complementary technical skills. From a marketing perspective, the seller is assigned an integrative role, developing a comprehensive view of the customer and the market and becoming a reliable customer consultant. As an R\&D director mentions, "The customer becomes the responsibility of the seller who supports him in the decision-making process. (...) The seller becomes a reliable customer consultant". Furthermore, the technical product owner must acquire commercial and marketing skills for understanding the business, the expected benefits and future needs of the customer, and for initiating proactive actions to offer solutions that the customer hasn't thought of.

Innovation for value creation requires the use of new technologies and equipment to develop new technical capabilities to create solutions to customer problems. Relevant in this regard is the description of the sales manager of an IT company in the sample that has become an IoT network operator, also providing data services: "Our company has developed new technological capabilities to become an IoT network operator, acquired and installed new HW equipment with software applications, sensors deployed, and network applications installed to provide data to customers or the community". 
Table no. 2. Business model innovation for IoT solutions

\begin{tabular}{|c|c|c|c|}
\hline $\begin{array}{l}\text { Third- } \\
\text { order } \\
\text { construct }\end{array}$ & $\begin{array}{l}\text { Second-order } \\
\text { constructs }\end{array}$ & $\begin{array}{l}\text { First-order } \\
\text { constructs }^{*}\end{array}$ & Codes \\
\hline \multirow{10}{*}{ 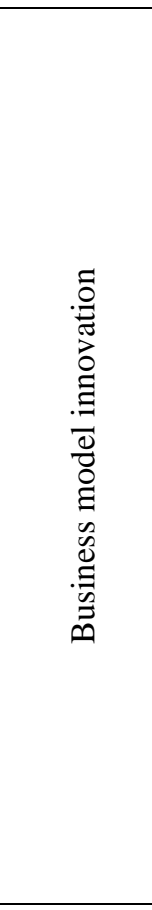 } & \multirow{4}{*}{$\begin{array}{l}\text { Value creation } \\
\text { innovation }\end{array}$} & $\begin{array}{l}\text { New } \\
\text { competencies }\end{array}$ & $\begin{array}{l}\text { New technical knowledge and skills } \\
\text { New marketing knowledge and skills }\end{array}$ \\
\hline & & $\begin{array}{l}\text { New technology } \\
\text { and/or equipment }\end{array}$ & $\begin{array}{l}\text { New technological capabilities } \\
\text { New equipment and software }\end{array}$ \\
\hline & & New partnerships & $\begin{array}{l}\text { IT partnerships } \\
\text { New specialized partners offering } \\
\text { complementary services }\end{array}$ \\
\hline & & New processes & $\begin{array}{l}\text { New IoT solution development } \\
\text { process } \\
\text { New market creation process }\end{array}$ \\
\hline & \multirow{4}{*}{$\begin{array}{l}\text { Value } \\
\text { proposition } \\
\text { innovation }\end{array}$} & New offerings & $\begin{array}{l}\text { Analytic services } \\
\text { New services through a sharing model }\end{array}$ \\
\hline & & $\begin{array}{l}\text { New customers } \\
\text { and markets }\end{array}$ & $\begin{array}{l}\text { New approach to the market } \\
\text { Demand from new customers }\end{array}$ \\
\hline & & New channels & Designing new direct channels \\
\hline & & $\begin{array}{l}\text { New customer } \\
\text { relationships }\end{array}$ & $\begin{array}{l}\text { Customization } \\
\text { Continuous interaction and } \\
\text { collaboration } \\
\text { Co-development }\end{array}$ \\
\hline & \multirow{2}{*}{$\begin{array}{l}\text { Value capture } \\
\text { innovation }\end{array}$} & \multirow[b]{2}{*}{$\begin{array}{l}\text { New revenue and } \\
\text { cost model }\end{array}$} & Product-as-a-Service model \\
\hline & & & $\begin{array}{l}\text { Low-cost solutions } \\
\text { Solution scalability }\end{array}$ \\
\hline
\end{tabular}

Note: *According to Clauss's (2017) conceptualization

New partnerships play a very important role in value creation innovation. Managers are trying to expand existing partnerships to reap the benefits of rapid access to information, increasing their ability to adapt to new trends by developing and promoting IoT solutions. The general manager of one company highlighted the efforts to "bring traditional IT partnerships to the IoT area", and an R\&D director argued that "specialized partners offering complementary services are needed to develop an IoT solution together. But it is necessary to have confidence that the partners carry out their tasks on time, respecting the agreed parameters".

Our qualitative data revealed two new processes representing innovations in value creation, namely the process of developing an IoT solution and the process of creating a new market. The IoT development process adopts a solution-centred approach to meet the needs and problems of customers, rather than a product-centred logic, the emphasis being on the ability of the IoT solution to generate value for the customer's business. The new market creation process for IoT solutions relies on identifying one first customer with a problem that could be addressed, deepening the customer knowledge and co-developing the solution together with the customer, developing a market positioning concept and promoting the solution to other customers in the same category. As a R\&D director explained, "The new IoT solution development process was designed in the logic of project management." 
B. Value proposition innovation. In developing new IoT solutions, the focus is on services, not devices. The managers interviewed revealed that their companies develop IoT solutions that provide non-invasive data capture services and real-time data that help managers to make better decisions which in turn create higher customer value. IoT developers are looking for standardization, modular architecture and scalability of the solutions they develop, allowing customers to integrate and customize these modules according to their needs and activities. Successful IoT solutions have proven to be simple, customized, easy to implement and low cost for customers. The provision of new solutions for the development of the customer's core business is particularly important. In this regard, summarizing his company's future plans, an $\mathrm{R} \& \mathrm{D}$ director said that "In the future, we will provide analytics services using algorithms that identify patterns in the data collected, thus creating new value for the customer. Instead of applications, customers request new services through a sharing model".

IoT developers focus on customer problems that can be solved by the real time data collected, displayed, and analyzed by the IoT solution. For example, an R\&D director highlights that his company "began providing air quality data collected by sensors in its IoT network. Requests were made by non-traditional customers like not-for-profit organizations".

The companies that develop IoT solutions create direct marketing channels. The process of customer communication and negotiation starts at the level of top management and operations managers (the latter as direct users of the proposed solution), in contrast to conventional IT products and services for which this process begins and takes place through the IT department. New collaborative relationships with customers were found to emerge. The sample companies develop the IoT solutions together with the customers, the process of co-creating value being a key success factor in the development and commercialization of new IoT solutions. The need for continuous interaction, communication and collaboration with the customer throughout the value creation process (i.e. discovering customer needs, designing the IoT solution, implementing, providing maintenance and updating the IoT solution) was highlighted. As the general manager of a company explained, "In the case of a solution for monitoring the manufacturing process, the idea arose during discussions with a customer about the possibility of monitoring the electricity consumption of the equipment. Then the idea of monitoring the operation of equipment based on monitoring electricity consumption crystallized, the IoT solution being developed together. Moreover, when the customer receives the first benefits that strengthen his trust, he requests the gradual expansion of the solution by adding new features."

C. Value capture innovation. Companies are put in a position to renew their revenue and cost models to capture value from the IoT solutions they develop. For example, Product-asa-Service was revealed as a new way of value capture, the customer paying for the service provided by IoT solution. Customers are a driving force behind the adoption of new revenue-generating model by requiring access to IoT solution as a service according to a sharing model rather than buying it as a unique product. From a cost perspective, the sample companies focus on developing simple, scalable, and easy to implement solutions to keep costs low to increase access and to intensify their use. The R\&D director of a company explained these aspects as follows: "There are many customers who discuss an IoT solution with us, then request it as a service, which leads to a different approach to the 
market. Thus, instead of applications, customers request services according to a sharing business model".

\subsection{Strategic factors of business model innovation for IoT solutions}

The company's strategic orientations (i.e. proactive market orientation, technology orientation, and entrepreneurial orientation), adaptive marketing capabilities, organizational culture and leadership play an important role in business model innovation for IoT solutions (Table no. 3).

Table no. 3. Strategic factors of business model innovation for IoT solutions

\begin{tabular}{|c|c|c|}
\hline $\begin{array}{l}\text { Second-order } \\
\text { constructs }\end{array}$ & $\begin{array}{l}\text { First-order } \\
\text { constructs }\end{array}$ & Codes \\
\hline \multirow{3}{*}{$\begin{array}{l}\text { Strategic } \\
\text { orientations }\end{array}$} & $\begin{array}{l}\text { Proactive market } \\
\text { orientation }\end{array}$ & $\begin{array}{l}\text { Recognizing customers' latent need } \\
\text { Setting market trend }\end{array}$ \\
\hline & $\begin{array}{l}\text { Technology } \\
\text { orientation }\end{array}$ & $\begin{array}{l}\text { Recognizing the business potential of the } \\
\text { new technologies } \\
\text { Development of IoT solutions }\end{array}$ \\
\hline & $\begin{array}{l}\text { Entrepreneurial } \\
\text { orientation }\end{array}$ & $\begin{array}{l}\text { Decision to act proactively } \\
\text { To be among the first movers }\end{array}$ \\
\hline \multirow{3}{*}{$\begin{array}{l}\text { Adaptive } \\
\text { marketing } \\
\text { capabilities* }\end{array}$} & $\begin{array}{l}\text { Vigilant market } \\
\text { learning }\end{array}$ & $\begin{array}{l}\text { Listening to customers } \\
\text { Identifying emerging trends and needs } \\
\text { New understandings of customer needs }\end{array}$ \\
\hline & $\begin{array}{l}\text { Market } \\
\text { experimentation }\end{array}$ & $\begin{array}{l}\text { Testing solutions in the real context of } \\
\text { customer use } \\
\text { Testing solutions on the market } \\
\text { Learning through experimentation }\end{array}$ \\
\hline & Open marketing & $\begin{array}{l}\text { Joining non-trade alliances } \\
\text { Promotion through virtual communities }\end{array}$ \\
\hline $\begin{array}{l}\text { Organizational } \\
\text { culture }\end{array}$ & Innovation culture & $\begin{array}{l}\text { Focus on innovation } \\
\text { Openness to new technologies }\end{array}$ \\
\hline $\begin{array}{l}\text { Organizational } \\
\text { leadership }\end{array}$ & Facilitative leadership & $\begin{array}{l}\text { Vision and imagination } \\
\text { Foreseeing business opportunities }\end{array}$ \\
\hline
\end{tabular}

Proactive market orientation was revealed as one of the important factors in business model innovation for IoT solutions. Proactive market orientation is about creating and developing a new market by offering IoT solutions that address customer problems and their unexpressed needs. In this regard, one general manager points out that "the role of the provider is to discover unexpressed customer needs and to convince customers to invest based on an opportunity cost of not adopting an IoT solution." Because customer awareness and readiness to adopt IoT solutions are low, adopting a proactive market orientation appears to play an important role in creating a new market.

At the same time, companies in the sample have a high level of technology orientation by recognizing ahead of their competitors the business potential of IoT technologies. Once the business opportunities opened by technology and market trends have been identified by top managers, the development of IoT solutions has become the focus of the company's strategy. An R\&D director explained this orientation towards technology: "The business 
potential of IoT and the complementarities with the specific core activities of the company have been identified. Initially, the innovation division focused on research, identifying new ideas and developing projects (...) that could lead to the discovery of new market niches and the development of proprietary solutions. Then, among market trends, the future business potential of the IoT was identified and became the focus."

The third strategic orientation adopted by companies in the sample is the entrepreneurial orientation. The companies in the sample are innovative and proactive in their strategic actions, taking the initiative and calculated risks to develop IoT solutions, and are among the first movers in the market. As one general manager explained, "Once top management understood the IoT phenomenon, we made the decision to be proactive, to be among the first to develop IoT solutions and to create a new IoT business".

The theoretical coding of our qualitative data led us to discover that adaptive marketing capabilities also play an important role in business model innovation for IoT solutions. The capability of vigilant market learning allows the generation of valuable insights about the latent and future needs of the customers. For example, an R\&D director pointed out that "they have identified the need for new solutions to ensure resource planning and product traceability, simultaneously solving the problem of capturing data from existing equipment". Thus, speaking and listening to customers are essential activities to discover unarticulated needs and to help identify potentially disruptive trends that require business model changes. In addition, IoT developers are expanding their understanding of how IoT technology can improve the customer's operations processes and how it can add value to the customer's business.

Adaptive market experimentation capability has been identified as an important factor in driving business model innovation. Some managers adopt a trial and error approach to conducting internal and market experiments to enhance learning and good practice development. The general manager of a company explained this approach as follows: "Initially, we test the IoT solution at home and only after that we offer it to the market. Testing products and services in the real context of customer use is essential. The feedback provided by the customer gives us the opportunity to learn how to continuously improve the quality of the products and services we offer to the market. Different types of solutions have been tested on the market and some of them have proven their viability."

Open marketing capability seems to play a significant role in driving business model innovation for IoT solutions. The IoT developers in the sample strive to integrate into alliances, business ecosystems, networks and communities for organizational learning and marketing communication. In this regard, an R\&D director pointed out that "The first thing was to join an alliance that aims to standardize a communication protocol to promote market development. The company benefits from access to information about this protocol, its standards and the accessibility of IoT technology solutions". Furthermore, these managers also leverage the resources of any external partners, such as virtual communities of interest, to build customer awareness and trust in IoT solutions.

An innovation-centred company culture has been revealed as a factor that encourages innovative behaviours such as experimenting with new technologies and business models. In this line, a general manager from the sample emphasized that "company culture stimulates openness to new technological trends". Encouraging the exploration of the unknown is an another interesting feature of this culture, as revealed by an R\&D director: 
"A company that is open to innovation facilitates the development of the IoT business by focusing on what employees do not yet know how to do."

Facilitative leadership plays an important role in innovation of the business model for IoT solutions. As one general manager pointed out, "the visionaries are the ones who foresee IoT business opportunity and imagine a new business model which they build in order to be successful in the market". Moreover, a common vision shared within the organization is essential in this process. The general manager of another company in the sample concluded that "The most important thing is to share the same vision, so that when the business model changes, everyone gets involved in implementing the vision and taking the risk".

\subsection{Performance outcomes of business model innovation for IoT solutions}

We discovered two main outcomes of business model innovation for IoT solutions, namely strengthening the competitive advantage of the company and increasing customer satisfaction (Table no. 4).

Table no. 4. Outcomes of business model innovation for IoT solutions

\begin{tabular}{|l|l|}
\hline \multicolumn{1}{|c|}{ First-order constructs } & \multicolumn{1}{c|}{ Codes } \\
\hline Competitive advantage & $\begin{array}{l}\text { Differentiation as competitive advantage } \\
\text { First mover }\end{array}$ \\
\hline Customer satisfaction & $\begin{array}{l}\text { Customer satisfaction } \\
\text { Customer delight }\end{array}$ \\
\hline
\end{tabular}

IoT developers expect to benefit from being among the first movers to gain a competitive advantage through IoT-enabled differentiation. In this regard, a sales manager revealed that "the company's aim in developing IoT solutions is to create a differential advantage over its competitors market through a unique value proposition". Customer satisfaction and delight seem to be a high priority for the managers of the companies in this sample, the right attitude towards the customer being an important factor of success in developing IoT solutions. In addition, we identified a concern about the risk of negatively affecting the corporate image through customer dissatisfaction resulting from unclear and/or excessive customer's expectations. A general manager highlighted that: "Ensuring customer satisfaction and delight is a priority for the company. The right attitude towards the customer is essential in developing a successful IoT solution".

To synthesize, this study provides empirical evidence that, in contexts characterized by uncertainty of the business environment as in the case of IoT solutions, strategic orientations of the company, adaptive marketing capabilities, facilitative leadership, and innovation-centred organizational culture have the potential to pave the way for successful business model innovation.

\section{Discussions}

Companies need to innovate continuously their business model in response to the uncertainty generated by technology and market changes in order to sustain their long-term competitive advantage (Foss and Saebi, 2018). Successful innovation of the business model for IoT solutions requires companies to adopt strategic orientations towards market, technology and entrepreneurship (Chesbrough and Rosenbloom, 2002). These strategic orientations generate a value system (Zhou, Yim and Li, 2005) and an external perspective 
in aligning the company's strategies with the environmental dynamics (Zhou and Li, 2010), creating the conditions for increasing long-term performance. Despite this, in the field of strategic management and marketing, limited efforts have been dedicated to studying the strategic factors of business model innovation for IoT solutions. To fill this knowledge gap, this paper contributes to deepening the understanding of the business model innovation phenomenon and guiding managers in this process.

First, this study identified links between proactive market orientation, technology orientation, and entrepreneurial orientation with business model innovation for IoT solutions. This is consistent with previous research in strategic marketing that demonstrates the positive influence of these strategic orientations on innovation and performance (Gatignon and Xuereb, 1997; Atuahene-Gima, 2001; Zhou, Yim and Tse, 2005). Second, the potential of adaptive marketing capabilities to facilitate business model innovation for IoT solutions was highlighted. This finding confirms the idea that capitalizing on the company's strategic orientations requires complementary resources such as marketing capabilities (Zhou, Yim and Li, 2005; Zhou and Li, 2010). Third, a facilitative leadership and an innovative organizational culture have been found to play an important role in stimulating business model innovation for IoT solutions. This finding is in line with previous empirical research that revealed the role of top management support in implementing market orientation (Narver and Slater, 1990) and the role of top managers in developing new capabilities for capitalizing on new technologies (Srinivasan, Lilien and Rangaswamy, 2002). Fourth, managers have formulated their expectation that competitive advantage and customer satisfaction will be the main results of business model innovation for IoT solutions. This is consistent with the results of previous research that supports the contribution of business model innovation to competitive advantage (Casadesus-Masanell and Zhu, 2013; Bashir and Verma, 2019) and to company performance (Karimi and Walter, 2016; Visnjic, Wiengarte and Neely, 2016).

\section{Conclusions}

This research makes some theoretical contributions to explaining the strategic factors of business model innovation for IoT solutions from the perspective of RBV theory. Thus, links were identified between proactive market orientation, technology orientation and entrepreneurial orientation with business model innovation for IoT solutions. Moreover, adaptive marketing capabilities have the potential to facilitate business model innovation for IoT solutions, while a facilitative leadership and an innovative organizational culture play an important role in supporting business model innovation for IoT solutions. Consequently, the competitive advantage and customer satisfaction are the main results of the innovation of the business model for the IoT solutions expected at the managerial level. From a methodological point of view, this paper expands the scope of Grounded theory in researching the phenomenon of business model innovation for IoT solutions in the context of an emerging economy.

The results of this research are relevant for business practice, providing managers with guidance in business model innovation for IoT solutions. Understanding the strategic factors of business model innovation for IoT solutions will help managers make decisions about developing the complementary assets and capabilities needed to facilitate business model innovation for IoT solutions and to take advantage of technological innovations. Capitalizing on technological innovations requires innovation both in terms of components 
and in the architecture of the business model. Consequently, managers need to allocate adequate resources to the development of new value propositions, new value creation processes and new value capture models. To achieve the expected outcomes from business model innovation, managers should ensure the development of adaptive marketing capabilities that provide valuable customer insights and relational assets. To enhance the company's adaptive marketing capabilities, managers should instil at the organizational and individual level the values and behaviours appropriate to the strategic orientations that lead to successfully innovation of the business models. More specifically, they should encourage and support employees to adopt in their actions the values and norms of proactive market orientation, technology orientation and entrepreneurial orientation.

No research can exhaustively explain the investigated phenomenon. Likewise, this research has its own limits that open new avenues for future research. First, from the perspective of building and validating a theory, the relationships between the company's strategic orientations, marketing capabilities and the outcomes of business model innovation have not been tested quantitatively due to the small number of companies that have started to develop such solutions. Consequently, further research could develop and test hypothesis regarding the relationships between these theoretical constructs using validated scales from the previous marketing and strategic management literature. Second, further research could investigate the role of other strategic orientations in driving successful business model innovation for IoT solutions. For example, it could be investigated the role of responsive market orientation in driving business model innovation and how it relates to proactive market orientation. Third, the role of innovation and technological capabilities in driving business model innovation for IoT solutions could be further investigated. Finally, how a company's proficiency in implementing new business model for IoT solutions influences the impact of business model innovation on firm performance requires further research. In this regard, the moderating role of dynamic and static marketing capabilities in the relationship between business model innovation and performance outcomes could be specifically addressed. Research on the impact of strategic orientations and organizational capabilities on business model innovation can be done through survey research using certain measurement scales developed and validated in previous research. For example, proactive market orientation can be measured using Narver, Slater and MacLachlan's (2004) scale, and dynamic marketing capabilities using the scale developed by Guo et al. (2018). The construct of business model innovation can be measured using the Clauss's (2017) scale, while in measuring expected performance the scales developed by Moorman and Rust (1999) and Vorhies and Morgan (2005) are useful.

\section{References}

Adams, P., Bodas Freitas, I.M., and Fontana, R., 2019. Strategic orientation, innovation performance and the moderating influence of marketing management. Journal of Business Reseach, 97, pp. 129-140.

Alberti-Alhtaybata, L.V., Al-Htaybat, K., and Hutaibat, K., 2019. A knowledge management and sharing business model for dealing with disruption: The case of Aramex. Journal of Business Research, 94, pp. 400-407.

Amit, R. and Zott, C., 2001. Value creation in e-business. Strategic Management Journal, 22(6/7), pp. 493-520. 
Aspara, J., Hietanen, J., and Tikkanen, H., 2010. Business model innovation vs. replication: Financial performance implications of strategic emphases. Journal of Strategic Marketing, 18(1), pp. 39-56.

Atuahene-Gima, K., 2001. An empirical investigation of the effect of market orientation and entrepreneurship orientation alignment on product innovation. Organization Science, 1(2), pp. 54-74.

Avlonitis, G.J. and Salavou, H.E., 2007. Entrepreneurial orientation of SMEs, product innovativeness, and performance. Journal of Business Research, 60, pp. 566-575.

Barbour, O. and Luiz, J., 2019. Embracing solutions-driven innovation to address institutional voids: The case of uber and the middle of the pyramid. California Management Review, 62(1), pp. 31-52.

Barney, J., 1991. Firm resources and sustained competitive advantage. Strategic Management Journal, 17(1), pp. 99-120.

Barney, J., 2014. How marketing scholars might help address issues in resource-based theory. Journal of the Academy of Marketing Science, 42, pp. 24-26.

Bashir, M. and Verma, R., 2019. Internal factors and consequences of business model innovation. Management Decision, 57(1), pp. 262-290.

Berthon, P., Hulbert, J.M., and Pitt, L.F., 1999. To Serve or create? Strategic orientations toward customers and innovation. California Management Review, 42(1), pp. 37-58.

Blocker, C.P., Flint, D.J., Myers, M.B., and Slater, S.F., 2011. Proactive customer orientation and its role for creating customer value in global markets. Journal of the Academy of Marketing Science, 39(2), pp. 216-233.

Brege, H. and Kindstrom, D., 2020. Exploring proactive market strategies. Industrial Marketing Management, 84, pp. 75-88.

Casadesus-Masanell, R. and Ricart, J.E., 2010. From strategy to business models and onto tactics. Long Range Planning, 43(2/3), pp. 195-215.

Casadesus-Masanell, R. and Zhu, F., 2013. Business model innovation and competitive imitation: The case of sponsor-based business models. Strategic Management Journal, 34(4), pp. 464-482.

Chen, Y.-C., Li., P.-C. and Evans, K.R., 2012. Effects of interaction and entrepreneurial orientation on organizational performance: Insights into market driven and market driving. Industrial Marketing Management, 41, pp. 1019-1034.

Chesbrough, H., 2007. Business model innovation: it's not just about technology anymore. Strategy and Leadreship, 35(6), pp. 12-17.

Chesbrough, H. and Rosenbloom, R.S., 2002. The role of the business model in capturing value from innovation: evidence from Xerox Corporation's technology spin-off companies. Industrial and Corporate Change, 11(3), pp. 529-555.

Chryssochoidis, G., Dousios, D. and Tzokas, N., 2016. Small firm adaptive capability, competitive strategy, and performance outcomes: Competing mediation vs. moderation perspectives. Strategic Change, 25(4), pp. 441-466.

Ciampi, F., Demi, S., Magrini, A., Marzi, G. and Papa, A., 2021. Exploring the impact of big data analytics capabilities on business model innovation: The mediating role of entrepreneurial orientation. Journal of Business Reseach, 123, pp. 1-13.

Clauss, T., 2017. Measuring business model innovation: Conceptualization, scale development, and proof of performance. $R \& D$ Management, 47(3), pp. 385-403. 
Covin, J.G. and Slevin, D.P., 1998. The influence of organization structure on the utility of an entrepreneurial top management style. Journal of Management Studies, 25(3), pp. 217-234.

Day, G.S., 2011. Closing the marketing capabilities gap. Journal of Marketing, 75(4), pp. 183-195.

Fang, E. and Zou, S., 2009. Antecedents and consequences of marketing dynamic capabilities in international joint ventures. Journal of International Business Studies, 40(5), pp. 742-761.

Foss, N.J. and Saebi, T., 2018. Business models and business model innovation: Between wicked and paradigmatic problems. Long Range Planning, 51(1), pp. 9-21.

Futterer, F., Schmidt, J. and Heidenreich, S., 2018. Effectuation or causation as the key to corporate venture success? Investigating effects of entrepreneurial behaviours on business model innovation and venture performance. Long Range Planning, 51(1), pp. 64-81.

Gatignon, H. and Xuereb, J.-M., 1997. Strategic orientation of the firm new product performance. Journal of Marketing Research, 34(1), pp. 77-90.

Guest, G., Bunce, A. and Johnson, L., 2006. How Many Interviews Are Enough? An Experiment with Data Saturation and Variability. Field Methods, 18(1), pp. 59-82.

Guo, H., Wang, C., Su, Z. and Wang, D., 2020. Technology Push or Market Pull? Strategic Orientation in Business Model Design and Digital Start-up Performance. Journal of Product Innovation Management, 37(4), pp. 352-372.

Guo, H., Xu, H., Tang, C., Liu-Thompkins, Y., Guo, Z. and Dong, B., 2018. Comparing the impact of different marketing capabilities: Empirical evidence from B2B firms in China. Journal of Business Research, 93, pp. 79-89.

Han, J.K., Kim, N. and Srivanstava, R.K., 1998. Market orientation and organizational performance: Is innovation a missing link? Journal of Marketing, 62(4), pp. 30-45.

Hortinha, P., Lages, C. and Lages, L.F., 2011. The trade-off between customer and technology orientations: Impact on innovation capabilities and export performance. Journal of International Marketing, 19(3), pp. 36-58.

Hult, G.T.M. and Ketchen Jr., D.J., 2001. Does market orientation matter? A test of the relationship between positional advantage and performance. Strategic Management Journal, 22(9), pp. 899-906.

Jaeger, N.A., Zacharias, N.A. and Brettel, M., 2016. Nonlinear and dynamic effects of responsive and proactive market orientation: A longitudinal investigation. International Journal of Research in Marketing, 33(4), pp. 767-779.

Jayachandran, S., Hewett, K. and Kaufman, P., 2004. Customer response capability in a sense-and-respond era: The role of customer knowledge process. Journal of the Academy of Marketing Science, 32(3), pp. 219-233.

Karimi, J. and Walter, Z., 2016. Corporate entrepreneurship, disruptive business model innovation adoption, and its performance: The case of the newspaper industry. Long Range Planning, 49(3), pp. 342-360.

Kohtamäki, M., Heimonen, J., Sjödin, D. and Heikkilä, V., 2020. Strategic agility in innovation: Unpacking the interaction between entrepreneurial orientation and absorptive capacity by using practice theory. Journal of Business Research, 118, pp. 12-25. 
Kozlenkova, I.V., Samaha, S.A. and Palmatier, R.W., 2014. Resource-based theory in marketing. Journal of the Academy of Marketing Science, 42, pp. 1-21.

Lamore, P.R., Berkowitz, D. and Farrington, P.A., 2013. Proactive/responsive market orientation and marketing-research and development integration. Journal of Product Innovation Management, 30(4), pp. 695-711.

Lumpkin, G.T. and Dess, G.G., 1996. Clarifying the entrepreneurial orientation construct and linking it to performance. Academy of Management Review, 21, pp. 135-172.

Martin, S.L. and Javalgi, R.G., 2016. Entrepreneurial orientation, marketing capabilities and performance: The Moderating role of Competitive Intensity on Latin American International New Ventures. Journal of Business Research, 69, pp. 2040-2051.

Mezger, F., 2014. Toward a capability-based conceptualization of business model innovation: Insights from an explorative study. $R \& D$ Management, 44(5), pp. 429-449.

Miller, D., 1983. The correlates of entrepreneurship in three types of firms. Management Science, 29(7), pp. 770-791.

Moorman, C., 1995. Organizational market information processing: Cultural antecedents and new product outcomes. Journal of Marketing Research, 32(3), pp. 318-335.

Moorman, C. and Rust, R.T., 1999. The role of marketing. Journal of Marketing, 62(SI), pp. 180-197.

Morris, M.H., and Paul, G.W., 1987. The relationship between entrepreneurship and marketing in established firms. Journal of Business Venturing, 2(2), pp. 247-259.

Mütterlein, J. and Kunz, R.E., 2017. Innovate alone or with others? Influence of entrepreneurial orientation and alliance orientation on media business model innovation. Journal of Media Business Studies, 14(3), pp. 173-187.

Narver, J.C. and Slater, S.F., 1990. The effect of a market orientation on business profitability. Journal of Marketing, 54, pp. 9-16.

Narver, J.C., Slater, S.F. and MacLachlan, D.L., 2004. Responsive and proactive market orientation and new-product success. Journal of Product Innovation Management, 21(5), pp. 334-347.

Oktemgil, M. and Gordon, G., 1997. Consequences of high and low adaptive capability in UK companies. European Journal of Marketing, 31(7), pp. 445-466.

Osterwalder, A., Pigneur, Y. and Tucci, C.L., 2005. Clarifying business models: Origins, present, and future of the concept. Communications of the Association for Information Systems, 16, pp. 1-25.

Ozdemir, S., Kandemir, D. and Eng, T.-E., 2017. The role of horizontal and vertical new product alliances in responsive and proactive market orientations and performance of industrial manufacturing firms. Industrial Marketing Management, 64, pp. 25-35.

Paiola, M. and Gebauer, H., 2020. Internet of things technologies, digital servitization and business model innovation in BtoB manufacturing firms. Industrial Marketing Management, 89, pp. 245-264.

Porter, M.E. and Happelmann, J.E., 2014. How smart, connected products are transforming competition. Harvard Business Review, 92(11), pp. 64-88.

Saeed, S., Yousafzai, S.Y. and Engelen, A., 2014. On Cultural and Macroeconomic Contingencies of the Entrepreneurial Orientation-Performance Relationship. Entrepreneurship Theory and Practice, 38(2), pp. 255-290. 
Saldaña, J., 2013. The coding manual for qualitative researchers. 2nd ed. London: SAGE Publications Ltd.

Slater, S.F. and Narver, J.C., 1995. Market orientation and the learning organization. Journal of Marketing, 59(3), pp. 63-74.

Srinivasan, R., Lilien, G.L. and Rangaswamy, A., 2002. Technological opportunism and radical technology adoption: An application to e-business. Journal of Marketing, 66(3), pp. 47-60.

Taran, Y., Boer, H. and Lindgren, P., 2015. A business model innovation typology. Decision Sciences, 46(2), pp. 301-331.

Teece, D.J., 2010. Business models, business strategy and innovation. Long Range Planning, 43(2/3), pp. 172-194.

Teece, D.J., 2018. Business models and dynamic capabilities. Long Range Planning, 51(1), pp. 40-49.

Tsai, K.-H., Chou, C. and Kuo, J.-H., 2008. The curvilinear relationships between responsive and proactive market orientations and new product performance: A contingent link. Industrial Marketing Management, 37, pp. 884-894.

Verhoef, P.C. and Bijmolt, T.H.A., 2019. Marketing perspectives on digital business models: A framework and overview of the special issue. International Journal of Research in Marketing, 36(3), pp. 341-349.

Visnjic, I., Wiengarten, F. and Neely, A., 2016. Only the brave: Product innovation, service business model innovation, and their impact on performance. Journal of Product Innovation Management, 33(1), pp. 36-52.

Vorhies, D.W. and Morgan, N.A., 2005. Benchmarking marketing capabilities for sustainable competitive advantage. Journal of Marketing, 69, pp. 80-94.

Wang, C.L. and Ahmed, P.K., 2007. Dynamic capabilities: A review and research agenda. The International Journal of Management Reviews, 9(1), pp. 31-51.

Wirtz, B.W., 2016. Business model management: Design process instruments, Textbook for the Digital Society. 2nd ed. Speyer: s.n.

Wirtz, B.W., Pistoia, A., Ullrich, S. and Gottel, V., 2016. Business models: Origin, development and future research perspectives. Long Range Planning, 49(1), pp. 36-54.

Zahra, S.A. and Neubaum, D.O., 1998. Environmental diversity and the entrepreneurial activities of new ventures. Journal of Developmental Entrepreneurship, 3(2), pp. 123-140.

Zhao, Y., Li, Y., Lee, S.H. and Chen, L.B., 2011. Entrepreneurial orientation, organizational learning, and performance: Evidence from China. Entrepreneurship: Theory and Practice, 35(2), pp. 293-317.

Zhou, K.Z. and Li, C.B., 2010. How strategic orientations influence the building of dynamic capability in emerging economies. Journal of Business Research, 63, pp. 224-231.

Zhou, K.Z., Yim, C.K.(B.) and Tse, D.K., 2005. The effects of strategic orientations on technology - and market-based breakthrough innovations. Journal of Marketing, 69(2), pp. 42-60.

Zott, C., Amit, R. and Massa, L., 2011. The business model: Recent developments and future research. Journal of Management, 37, pp. 1019-1042. 